Japan. J. Breed., 30(3): 231 236 (1980)

\title{
Interspecific Hybrids of Jute between Corchorus olitorius L. and Semi-wild C.capsularis L.
}

\author{
M. Haque, L. A. Khan, M. Rahman, A. Rahman and A. S. Islam \\ Plant Breeding Laboratory, Department of Botany, Dacca \\ University, Dacca-2, Bangladesh
}

\begin{abstract}
Hybridization between Corchorus olitorius L. and C.capsularis L. was repeated by changing the variety of one of the parents. Using a semi-wild species of C.capsularis, namely, Lalnaris as male parent instead of the cultivar D 154, much $F_{1}$ hybrids were obtained whereas in the earlier cross application of hormone as well as embryo culture were necessary to obtain $F_{1}$ hybrids. When Lalnaris was used there was no necessity to use either hormone or embryo culture to obtain fruit set. The $F_{1} s$ obtained in the present investigation showed heterosis in respect of height and there was less variability in the $\mathrm{F}_{2}$. They also showed more pollen and seed fertility than the $\mathrm{F}_{2} \mathrm{~s}$ reported earlier.
\end{abstract}

\section{Introduction}

By means of various techniques, such as by suppressing the formation of abscission layer at the pedicel of the pollinated flowere with the help of IAA, culturing the hybrid embryos in artificial medium, using pollen of the male species grafted on to the female species, it has been possible in the past to obtain reasonably fertile $F_{1}$ hybrids between C. olitorius and C.capsularis (Islam and Rashid 1960. Swaminathan et al. 1961, Haque and LsLam 1969).

In spite of the initial success no improved strain could be isolated from the above hybrid derivatives. The lack of success was due to the reversion of the progeny to only parental type in $\mathrm{F}_{4}$ and subsequent generations. Since there is a great need to evolve varieties from the cross of the above two cultivar species, attempts were made to circumvent the barrier of crossability by hybridizing the olitorius cultivar with (a) a semi-wild race of capsularis as well as with (b) $\mathrm{F}_{1} \mathrm{~s}$ of the cross, cultivar capsularis $\mathrm{x}$ semi-wild capsularis. In the following account, the result of the above attempt is reported.

\section{Materials and Methods}

The following Corchorus species and the hybrid progenies were used in the present work:

(1) Corchorus olitorius L., cv. 04, $2 \mathrm{n}=14$

(2) C. capsularis L., race Lalnaris, semi-wild, $2 \mathrm{n}=14$

(3) C.capsularis L., CV. D 154, $2 \mathrm{n}=14$

(4) (04 Lalnaris) $\mathrm{F}_{1}$

(5) (04 $\times$ Lalnaris) $\mathrm{F}_{2}$

(6) $(04 \times($ D $154 \times$ Lalnaris $)) F_{1}$

To avoid the chance of self-pollination emasculation was done on the previous evening and the flowers emasculated were covered with the paper bags/gelatine capsules. Pollination was made in the following morning between 7.30 and 8.30 A.M.

Received December 21, 1979 
Morphology of the parental plants: For morphological description of the two cultivars of C.olitorius and C.capsularis, namely 04 and C. G. respectively Hooker's Flora of British India Vol. 1 may be referred to (MAsters 1874). Since no description of Lalnaris is available, in the following accout Lalnaris has been compared with D 154.

C. capsularis L. Lalnaris: Annual, profusely branched herb, usually attaining a height of $78.2 \pm 10.5 \mathrm{~cm}$. Stem: bushy, red, cylindrical with a base diameter of $0.84 \pm 0.01 \mathrm{~cm}$, angle of branching $41.6 \pm 4.1^{\circ}$. Leaves: similar to cultivar but much smaller in size with smaller $\mathrm{B} / \mathrm{L}$ ratio, colour green with reddich tinge, venation not pronounced like cultivar, pale red, petiole and stipule dull red like the stem color. Flower: like those of cultivar except that there are slightly smaller in size with a smaller number of stamens (17.2 3.4 as against $20.0 \pm 4.3$ in cultivar), flower buds characterised by a red tip. Characteristics of fruit and seed are like the cultivars.

\section{Results}

\section{(a) $04 \times$ Lalnaris and its $F_{1}$ hybrids}

One hundred and thirty three crosses were made using 04 of C.olitorius as female and Lalnaris as male. Although the number of fruit set was 93, finally 87 fruits were harvested, of these only 34 contained viable seeds. The percentage of viable hybrid seeds was 21. Hybrid seeds along with the control parents were timely sown in rows in the experimental plot. The percentage of germination of hydrid seeds was 83 as against 97 in 04 and 98 in Lalnaris control (Table 1). A total of $163 \mathrm{~F}_{1}$ s were obtained. Both $F_{1}$ s and their parents flowered simultaneously. Out of the $163 F_{1} s 76$ were branced and 87 unbranced (branches were recorded after they had been in flower). The absence of branch may be due to the imperfect penetrance of the gene responsible for branching. The $\mathrm{F}_{1} \mathrm{~s}$ attained a greater height $(275.8 \pm 80.6 \mathrm{~cm})$ compared to 04 control $(224.0 \pm 43.3$ $\mathrm{cm}$ ). The greater height attained by the $F_{1}$ s indicated that in spite of their being interspecific hybrid they showed heterosis in respect of height. The $\mathrm{F}_{1}$ s were also dominant in respect of the base diameter.

The angle of branching was $40.6 \pm 6.7^{\circ}$ in the $F_{1}$ s as against $43.9^{\circ}$ in profusely branched Lalnaris and no branching in 04 . The internodal distance in the $F_{1} \mathrm{~s}$ was $5.5 \pm 0.0 \mathrm{~cm}$ compared to $6.3 \pm 1.1 \mathrm{~cm}$ in 04 and $2.2 \pm 0.5 \mathrm{~cm}$ in Lalnaris indicating that the $F_{1} \mathrm{~s}$ were intermediate in respect of internodal distance. The $\mathrm{F}_{1} \mathrm{~s}$ were also intermediate in respect of petiole length and number of seeds per fruit. $B / L$ ratio of the leaves in the $F_{1} s$ was $0.47 \pm 0.53$; in 04 and Lalnariaris these figures were $0.48 \pm 0.07$ and $0.09 \pm 0.07$ respectively.

The percentage of fertile pollen grains in $F_{1} s$ was 94.4 as against 96.1 in 04 and 98.6

Table 1. Details of crossing results

\begin{tabular}{|c|c|c|c|c|c|c|c|}
\hline \multirow{2}{*}{ Parents } & \multirow{2}{*}{$\begin{array}{l}\text { No. of } \\
\text { crosses }\end{array}$} & \multirow{2}{*}{$\begin{array}{l}\text { No. of } \\
\text { fruit } \\
\text { set }\end{array}$} & \multirow{2}{*}{$\begin{array}{l}\% \text { of } \\
\text { fruit } \\
\text { set }\end{array}$} & \multirow{2}{*}{$\begin{array}{l}\text { No. of fruits } \\
\text { with mature } \\
\text { seeds }\end{array}$} & \multirow{2}{*}{$\begin{array}{l}\text { Tatal no. } \\
\text { of mature } \\
\text { seeds }\end{array}$} & \multicolumn{2}{|c|}{$\%$ of germination } \\
\hline & & & & & & $\begin{array}{l}\text { Seeds } \\
\text { sown }\end{array}$ & $\begin{array}{l}\text { No. of seeds } \\
\text { germinated }\end{array}$ \\
\hline $\begin{array}{l}\text { C. olitorius var } 04 \times \\
\text { C. capsularis var } \\
\text { Lalnaris }\end{array}$ & 133 & 93 & 69 & 34 & 714 & 253 & $209(83 \%)$ \\
\hline$(04 \times$ Lalnaris $) F_{1}$ & 38 & 28 & 73 & Not observed & 3429 & 3429 & $2572(75 \%)$ \\
\hline $\begin{array}{l}04 \times(\mathrm{D} 154 \times \\
\text { Lalnaris }) \mathrm{F}_{1}\end{array}$ & 137 & 90 & 66 & 27 & 816 & 356 & $316(89 \%)$ \\
\hline
\end{tabular}


in Lalnaris. This was an interesting observation because the interspecific hybrids are usually characterised by a considerable percentage of sterile pollen. However, it was not asertained whether all the stained PGs of the hybrid were viable. The number of seeds per fruit in $\mathrm{F}_{1} \mathrm{~s}$ was $121.5 \pm 27.1$ compared to $155.2 \pm 93.1$ in 04 and $37.1 \pm 6.4$ in Lalnaris.

(b) (04 $\times$ Lalnaris $) \mathbf{F}_{1}$

Among the $F_{1}$ plants only those which showed heterosis in respect of plant height combined with smaller number of branches at the base were selected for selfing. Out of 38 $F_{1}$ selfed flowers 23 fruits were obtained and these yielded 3429 viable seeds (80\%). All $\mathrm{F}_{2}$ seeds were initially sown in seed bed. The percentage of germination was 75 (Table 1). When the $\mathrm{F}_{2} \mathrm{~s}$ were one month old, segregation was studied in respect of stem, stipule, petiole color. It was observed that out of $2572 \mathrm{~F}_{2} \mathrm{~s}, 1941$ were red and 631 were green. This segregation showed a $3: 1$ ratio ( $\mathrm{P} 69 \%$ ).

After the above segregation study was over, nearly 450 healthy $F_{2}$ seedlings were removed at random and transplanted in plot. There were 388 mature plants for detailed study.

The $\mathrm{F}_{2} \mathrm{~s}$ obtained a height of $175.9 \pm 38.1 \mathrm{~cm}$ as against $275.8 \pm 80.6 \mathrm{~cm}$ in $\mathrm{F}_{1} \mathrm{~s}, 240.3 \pm$ $52.4 \mathrm{~cm}$ in 04 and $78.2 \pm 10.5 \mathrm{~cm}$ in Lalnaris. This showed that the height of $\mathrm{F}_{2} \mathrm{~s}$ decreased compared to $F_{1} s$ and this was probably due to the fact that the $F_{2} s$ were grown at a later date than the normal time. No clear cut ratio was obtained in the segregation of branching vs non-branching character (233 unbranched and 155 branched). None of the $\mathrm{F}_{2} \mathrm{~s}$ were found to be as tall as the control 04, a fact which suggests that the inheritance of branching character is neither monogenic nor digenic.

Out of $388 \mathrm{~F}_{2} \mathrm{~s}, 283$ were red and 105 were green both in their stem and stipule. The chi-square test showed a $3: 1$ ratio (p 60\%).

The base diameter in $\mathrm{F}_{2} \mathrm{~S}$ was found to decrease compared to both $\mathrm{F}_{1} \mathrm{~s}$ and the control 04. The petiols length in $\mathrm{F}_{2} \mathrm{~s}$ showed heterosis over $\mathrm{F}_{1} \mathrm{~s}$ and control 04 . The $\mathrm{B} / \mathrm{L}$ ratio of leaves in $F_{2} s$ was $0.46 \pm 0.06$ as against $0.47 \pm 0.00$ in $F_{1} s$ and $0.39 \pm 0.04$ in 04 .

04 was backcrossed to about 35 green and red stemmed $\mathrm{F}_{2} \mathrm{~s}$. Since it was observed that fruit set was not normal, $300 \mathrm{ppm}$ indole acetic acid in lanolin paste was smeared around the pedicel of the pollinated flowers. The use of hormone improved the average fruit set from 58 to $78 \%$ as shown in Table 2. The fruit size was larger in hormone treated crosses.

(c) $04 \times(D 154 \times$ Lalnaris $) F_{1}$ and its $F_{1}$ hybrids

One hundred thirty seven crosses were made using 04 as female and the apparently healthy looking selected $F_{1}$ s of the cross, D $154 \times$ Lalnaris. Although the fruit set was

Table 2. Percentage of fruit set in the backcross of (04×Lalnaris) $F_{2}$ to 04

\begin{tabular}{|c|c|c|c|c|c|}
\hline \multicolumn{2}{|c|}{ Parents } & \multicolumn{2}{|c|}{ No. of fruit treated } & \multicolumn{2}{|c|}{$\begin{array}{l}\text { No. of fruit } \\
\text { (percent of fruit set) }\end{array}$} \\
\hline Female & Male & $\begin{array}{l}\text { With } \\
\text { hormone }\end{array}$ & $\begin{array}{l}\text { Without } \\
\text { hormone }\end{array}$ & With $(\mathrm{H})$ & Without $(\mathrm{H})$ \\
\hline 04 & $\mathrm{~F}_{2}$ (Green) & 30 & 35 & $26(86 \%)$ & $24(68 \%)$ \\
\hline 04 & $\mathrm{~F}_{2}(\mathrm{Red})$ & 30 & 33 & $21(70)$ & $16(48)$ \\
\hline \multicolumn{2}{|c|}{ Mean } & - & 一 & $-(78)$ & $-(58)$ \\
\hline
\end{tabular}


higher $(66 \%)$ comparatively a small number (27) of fruits contained viable seeds and the remaining fruits were found to contain only inviable seeds. Viable seeds were sown timely direct in the field. The percentage of germination was 89. A total of 231 mature $\mathrm{F}_{1} \mathrm{~s}$ was obtained, of these 53 were branced and 178 were unbranched.

The $F_{1} \mathrm{~s}$ attained a height of $251.1 \pm 73.9 \mathrm{~cm}$ compared to $224.0 \pm 43.1 \mathrm{~cm}$ in 04 and $180.0 \pm 46.6 \mathrm{~cm}$ in the $F_{1} \mathrm{~s}, \mathrm{D} 154$ and Lalnaris. The $\mathrm{F}_{1} \mathrm{~s}$ were more vigorous and were better than 04, displaying better performance (heterosis in respect of height) of the interspecific over intraspecific hybrids.

The base diameter of $\mathrm{F}_{1} \mathrm{~s}$ was found to be intermediate between the two parents (1.26 $\pm 0.35 \mathrm{~cm}$ in the interspecific $F_{1} \mathrm{~s}, 1.04 \pm 0.28 \mathrm{~cm}$ in 04 and $1.47 \pm 0.51 \mathrm{~cm}$ in (D $154 \times$ Lalnaris) $\mathrm{F}_{1}$ ).

The number of stamens in $F_{1} \mathrm{~s}$ was intermediate between the parents. The percentage of pollen stainability was 95.8 in $F_{1}$ s compared to 96.1 in 04 and 98.1 in (D $154 \times$ Lalnaris) $F_{1}$ s. $\quad F_{1} s$ showed dominance of elongated pod size of the female parent (04) over the globular pod of the male. Only the fruits of red stemmed $F_{1}$ individuals showed red streaks along the furrows. 04 had no such red streaks while Lalnaris had red streaks with greenish tinge. The number of seeds per fruit was $123.9 \pm 28.9$ in $F_{1}$ s as against 155. $2 \pm 33.1$ in 04 and $31 \pm 11.7$ in (D $154 \times$ Lalnaris) $F_{1}$ s.

\section{Discussion}

The present attempt was made to hybridize the two cultivar jute species via a semiwild race of C.capsularis, namely Lalnaris as male parent. Although the earlier workers (Islam and Rashid 1960, Swaminathan et al. 1961, Chaudhury and Mia 1961, Mia and Shaikh 1967, Haque and Islam 1967) succeeded on producing partially fertile hybrid between the two cultivars, they reported high interspecific incompatibility. In the present crosses such as $04 \times$ Lalnaris and $04 \times$ (D $154 \times$ Lalnaris) $F_{1}$ no such incompatibility was experienced; instead high percentage of fruit set as well as a good number of highly fertile $\mathrm{F}_{1} \mathrm{~s}$ were obtained. ISLAM and RASHID (1960) used hormone (IAA) around the pedicel of the pollinated flowers to enhance the pollen tube growth and arrest earlier formation of abscission layer in the pedicel of the pollinated flower. Both Swaminathan et al. (1961) and MIA and Sнaikн (1967) used irradiated pollen of the male parent to obtain $\mathrm{F}_{1}$ hybrids. Haque and IsLAm (1967) used hormone and embryo culture technique for the same purpose. In the present case simply crosses were made replacing cultivar D 154 of capsularis with Lalnaris. Almost all the earlier workers including HAQUE and IsLAM (1967) reported a low percentage of fruit set and the $F_{1}$ hybrids they obtained were few in each case. Here the fruit set was high and a good number of $F_{1}$ plants were obtained. The $F_{1}$ s reported by earlier workers showed a low percentage of both pollen and seed fertility both of which improved in subsequent generations. Unlike the earlier $F_{1} s$ the present $F_{1}$ populations showed a high pollen and seed fertility.

In the past there were doubts about the hybrid nature of the two cultivar jute species but in the present case the hybrid nature of the $F_{1}$ plants could be proved because of the dominance of the male parent in respect of red pigment of (a) stem and (b) flower but tip. The high pollen fertility of the present $F_{1} s$, unlike those of the $F_{1}$ s obtained 
by Islam and Rashid (1960), HaQue and Islam (1967) indicated that Lalnaris, a semiwild race of capsularis was more closely related to the cultivar olitorius than the cultivar of capsularis, namely D 154.

It may be mentioned here that in interspecific crosses such as Nicotiana has often been achieved when the variety of a species has been changed in the cross.

Islan and RAShid (1960) and Haque and Islam (1967) reported that the hybrid between C. olitorius cv. C. G. and C.capsularis, cv. D 154 showed dominance of the male parent in respect of (a) B/L ratio of leaf, (b) notch in the upper margin of the petal and (c) pollen grain diameter. On the other hand in the character of (1) serration of leaf, (2) shape of the flower bud, (3) shape of the fruit and (4) presence of ribs on the fruit wall, their $F_{1}$ s showed the dominance of female character. Their hybrids were intermediate in characters of (a) stipule, (d) size of flower bud (c) color of petals and (d) size of petals.

The present $F_{1}$ hybrid population showed heterosos in height and base diameter over 04, the female parent; on the other hand they displayed the red pigmentation in all the plant parts i.e. in stem, flower tip, etc. like their male parent.

It may be mentioned here that the $\mathrm{F}_{1}$ hybrids of C.olitorius $\times$ C.capsularis reported earlier by the present authors and Swaminathan et al. (1961) were far from being transgressive in height and base diameter, and they were weak and dwarf with considerable sterility. The heterosis observed in the present population must therefore be ascribed to the fact that Lalnaris and D 154 differ a great deal in respect of their genotype.

The $\mathrm{F}_{2} \mathrm{~s}$ showed segregation in respect of green vs red pigmented individuals. Similar ratio was obtained (HAQUE 1970) in respect of color in stem and other plant parts in the hybrid derivatives of the advanced generation of a natural interspecific cross, C.olitorius $\times$ C. aestuans.

The $\mathrm{F}_{1}$ individuals showed further improvement in pollen fertility and the percentage was found to be almost equal to that of the parents. HAQUE and IsLam (1967) pointed out that once a hybrid is obtained in any interspecific cross of the genus Corchorus, the extent of fertility improves in subsequent generations.

\section{Literature Cited}

Chaudhury, S.D. and Jabbar Mia 1961. Species crosses in the geneu Corchorus (Jute plants), Euphytica, $11: 61 \sim 64$.

HaqUe, M. and A. S. Islam 1967. Reproduction of "Tossa-Daisee" jute hybrid. Sind Univ. Sci. Res. Jour., $3: 83 \sim 89$.

HAQUE, M. and A.S. IsLAm 1969. Some promising backcross derivatives of Corchorus olitorius $\times$ C. aestuans natural hybrid. Sind Univ. Sci. Res. Jour., $4: 123 \sim 130$.

HaQUE, M. 1970. Attempts to breed better and disease resistant jute (Corchorus) strains through Inter- and Intraspecific crosses. Ph. D. thesis, Sind University, Pakistan.

Istam, A.S. and A. RASHid 1960. First successful hybridization between the two jute yielding species, Corchorus olitorius, L. (Tossa) $\times$ C. capsularis L. (White). Nature, $185: 258 \sim 259$.

Masters, M. T. 1874. Flora of British India. (ed) Hooker, J. B. $1: 397$.

Mra, M. M. and A.Q. ShaIKH 1967. Gamma radiation and interspecific hybridization in jute (C.capsularis L. and C. olitorius L.). Euphytica, 16(1): 61 68.

Swaminathan, M. S., R. D. Iyer and K. Sulbiha 1961. Morphology, cytology and breeding behaviour between C. olitorius L. and C. capsularis L. Curr. Sci., $30: 67 \sim 68$. 
ジュート飞特けるCorchorus olitorius L. と半野生 C.capsularis L. との種間雑種

M. Haque, L. A. Khan, M. Rahman, A. Rahman • A. S. Islam

(バングラディシュ,ダッカ大学)

これまでジュートでは C.olitorius L.と C.capsularis L. との種間雑種は通常の交雑では困難であった。 しかしながら，C.capsularis L. の半野生種を母体に用いることによって，かなり容易に雑種を得ることがで きた。光られた個体は，雑種強勢を示し高い種子稔性を示した。 